\title{
Prevalence of Smoke-Free Zone Compliance among Schools in Indonesia: A Nationwide Representative Survey
}

\author{
Al Asyary ${ }^{1,2 *}$, Meita Veruswati ${ }^{2,3,4}$, Cut Putri Arianie ${ }^{5}$, Theresia Sandra Diah \\ Ratih $^{5}$, Aries Hamzah ${ }^{5}$
}

\begin{abstract}
Background: With the increasing prevalence of teenage or school-age smokers, schools have become the main focus of the Indonesian government in tobacco control, including through the smoke-free zone (SFZ) policy. This study aims to obtain information related to the implementation of SFZ policies in schools. Methods: A nationally representative survey was employed in 900 elementary, junior high, and senior high schools that were located in 60 regions or 24 provinces of Indonesia. Each school's compliance with SFZ parameters was measured using a closedended questionnaire. The dataset was analyzed using frequency distribution, while the chi-square was performed to analyze the measurement effect of each parameter for SFZ compliance. Results: Java Island is the region with the largest proportion of school units (10\%) studied in this study, and the largest group of the schools are high schools (36.1\%). In terms of SFZ compliance, 413 (45.9\%) of schools had perfect compliance scores of 8, followed by 183 schools $(20.3 \%)$ with a score of 7 and $107(11.9 \%)$ with a score of 6 . It was found that parameter 5, namely cigarette butts found in the school environment, had the largest proportion when a school did not apply SFZ. Cigarette butts were found in $261(29.0 \%)$ schools. Cigarette butts found in schools contributed 7.8 times to not applying SFZ compared to schools where no cigarette cutters were found. Conclusion: Although the SFZ compliance rate in Indonesian schools is $66.2 \%$ at least on 7 of 8 existed parameters, this means most of schools still aren't fully complying with the regulations for SFZs. This recent evidence will help decisionmakers to enforce tobacco control, particularly among youth, which form the pillar of national development.
\end{abstract}

Keywords: Smoke-free policy- schools- tobacco use cessation- environmental tobacco smoke

Asian Pac J Cancer Prev, 22 (2), 359-363

\section{Introduction}

A smoke-free zone (SFZ) is a room or area where it is declared that producing, selling, advertising, or promoting tobacco products and/or smoking activities is prohibited (Ministry of Health - Republic of Indonesia and Ministry of Home Affairs - Republic of Indonesia, 2011). SFZs include health service facilities, teaching and learning places, places of worship, children's playgrounds, public transportation, workplaces, public places, and other designated places (Ministry of Health - Republic of Indonesia, 2011).

Protecting the community from the dangers of cigarette smoke through the implementation of SFZs is expected to change behavior towards a healthy lifestyle and will be able to reduce morbidity and mortality from non-communicable diseases (Veruswati et al.,
2018). It is known that the percentage of deaths from non-communicable diseases in Indonesia is high compared to other developing countries in Asia-Pacific (Prasad and Sy, 2020). Smoking is one of the main risk factors for NCD. The prevalence of smokers aged 10-18 years according to Riskesdas 2018 reached 9.1\%, while the percentage of Indonesian population aged $\geq 15$ years who smoked according to the 2013 Riskesdas data was $36.3 \%$ (Balitbangkes, 2013).

The implementation of SFZ in schools is an effort to improve the quality of human life, which is one of the goals of the Indonesian government set forth in Nawa Cita (Widodo, 2014). In the 2015-2019 of Medium-Term National Development Plan (RPJMN), the target of the prevalence of smoking in the population aged $\leq 18$ years was $5.4 \%$ in 2019, and in the 2015-2019 Strategic Plan, one indicator of the government's action

${ }^{1}$ Department of Environmental Health, Faculty of Public Health, Universitas Indonesia, Depok, Indonesia. ${ }^{2}$ Center for Education and Community Services, Faculty of Public Health, Universitas Indonesia (P3M FKM UI), Depok, Indonesia. ${ }^{3}$ PhD Student in Business and Management, Management and Science University, Kuala Lumpur, Malaysia. ${ }^{4}$ Department of Public Health Science, Faculty of Health Sciences, Universitas Muhammadiyah Prof. Dr. HAMKA (UHAMKA), Jakarta, Indonesia. ${ }^{5}$ Directorate of Non-Communicable Disease Control and Prevention (P2PTM), Indonesian Ministry of Health, Jakarta, Indonesia. *For Correspondence: al.asyary@ui.ac.id 
on NCDs (PP-PTM) is the percentage of districts/cities that have SFZ policies in at least $50 \%$ of schools, with a target of $50 \%$ in 2019 .

The evaluation activities of SFZ implementation in selected representative provinces aim to investigate and estimate the prevalence of the implementation of SFZ policies in schools. In addition, the results can be in the form of an evaluation, which is expected to be able to encourage the local government of the city/regency to play an active role in supporting the application of SFZ-related regulations in their area.

\section{Materials and Methods}

\section{Study design}

This study obtained the secondary data from the national survey on tobacco control entitled, "Review Implementasi Kebijakan Kawasan Tanpa Rokok Di Sekolah/The Review on the Implementation of SFZ Policy in School". This nationally representative survey was employed by the Indonesian Health Ministry in eight parameters identified as smoke-free zones under Government Act No. 36 of 2009 in schools.

This study employed stratified cluster sampling. All schools in selected regency/city (regions) of province were derived as samples which is stratifying by representativeness of rest regency/city in those Indonesia provinces.

\section{Setting}

A 900 formal of schools consisted of elementary schools, junior high schools, and senior high schools were surveyed that located on 60 regions or 24 provinces of Indonesia. From all of these 60 regions as cluster, all state schools were collected as samples. These formal state schools included elementary, junior high, and senior high schools. The study was initiated in July 2019 and approved in early August 2019. The duration was three months, from mid-October to December 2019.

\section{Data sources/measurement}

Each school's SFZ parameters were measured using a closed-ended questionnaire, while its compliance with SFZ was determined using two measurement results: compliant and noncompliant with SFZ. A school is said to have implemented SFZ if it has a score $\geq 8$, while it is said not to have implemented it if it has a score $<8$. The division of categories is based on 8 parameters of the Joint Regulation of Minister of Health with Minister of Education and Culture (Permenkes and Permendikbud) regarding SFZ conducted in schools within 24 provinces and 60 districts/cities in Indonesia (Ministry of Health - Republic of Indonesia and Ministry of Home Affairs Republic of Indonesia, 2011).

Assessment of SFZ implementation was conducted by looking at the assessment form and interpreting the results of achievement based on the data inputted. The central officer collected and compiled all instruments from the regional enumerators, followed by data validation to ascertain whether the data were complete and the correct way to fill the assessment form. The staff would then discuss the resulting data before entering them and preparing a draft activity report.

\section{Study size}

A total of 900 schools were selected for this study, which represented all of primary educations as part of a population study. Clustered-random sampling with a WHO-Lameshow sample size obtained the sample's size with $10 \%$ added, hindering abnormal data distribution (outlier effects).

\section{Statistical analysis}

The dataset was analyzed using frequency distribution techniques. It held to discuss the achievement of SFZ compliance among these schools. In addition, chi-square was performed to analyze the measurement effect of each parameters to SFZ compliance and determined whether significance existed.

\section{Ethical approval}

The Indonesian Ministry of Education and Culture and the Indonesian Ministry of Health worked together to design and implement the survey. This national survey was conducted in accordance with the Helsinki Declaration where the study protocol had been submitted for consideration, comment, guidance and approval to a research ethics committee of Indonesian Ministry of Health as well as Indonesian Association of Public Health Expert before the study begins (No. 125/KEPK-IAKMI/ VII/2020).

\section{Results}

This study examines 900 schools as the unit of analysis in 24 provinces of Indonesia. The provinces on Java Island are the regions with the largest proportion of school units studied in this study. The largest group of schools were in West Java Province with 90 schools (10.0\%), followed by Central Java Province and East Java Province with 60 schools (6.7\%) each. North Sumatra Province, Riau Province, Jambi Province, Bengkulu Province, Gorontalo Province, Maluku Province, and North Maluku Province each had the smallest proportion of schools studied with 15 schools (1.7\%) each (Table 1$)$.

The current condition of schools regarding the implementation of SFZ was assessed using eight parameters based on the rules in Permenkes and Permendikbud on non-smoking areas. Each parameter has a value of 1 for a school that meets it and 0 if it does not. The description of school compliance can be seen in the Table 2 below:

On Table 2 shows also that 596 schools $(66.2 \%)$ have implemented at least 7 of 8 SFZ parameters $(>7)$ in their environment, compared with 304 schools $(33.8 \%)$ that have not. Based on the Table 2, the plurality of schools $(n=413 ; 45.9 \%)$ have a compliance score of 8 , or a perfect score, followed by 183 schools $(20.3 \%)$ that score 7 and $107(11.9 \%)$ with a score of 6 . There are $45(5.0 \%)$ schools with a score of 0 , which is the lowest score.

Based on the results of the inferential analysis above, it was found that parameter 5, namely cigarette butts found 
Table 1. Frequency Distribution by Region

\begin{tabular}{|c|c|c|c|}
\hline No & Province & $\mathrm{f}$ & $\%$ \\
\hline 1 & Aceh & 45 & 5.0 \\
\hline 2 & North Sumatera & 15 & 1.7 \\
\hline 3 & West Sumatera & 45 & 5.0 \\
\hline 4 & Riau & 15 & 1.7 \\
\hline 5 & Jambi & 15 & 1.7 \\
\hline 6 & Bengkulu & 15 & 1.7 \\
\hline 7 & South Sumatera & 45 & 5.0 \\
\hline 8 & Lampung & 30 & 3.3 \\
\hline 9 & Banten & 45 & 5.0 \\
\hline 10 & West Java & 90 & 10 \\
\hline 11 & Central Java & 60 & 6.7 \\
\hline 12 & East Java & 60 & 6.7 \\
\hline 13 & East Nusa Tenggara & 45 & 5.0 \\
\hline 14 & West Kalimantan & 45 & 5.0 \\
\hline 15 & South Kalimantan & 45 & 5.0 \\
\hline 16 & Central Kalimantan & 45 & 5.0 \\
\hline 17 & East Kalimantan & 30 & 3.3 \\
\hline 18 & Gorontalo & 15 & 1.7 \\
\hline 19 & South Sulawesi & 45 & 5.0 \\
\hline 20 & South-east Sulawesi & 30 & 3.3 \\
\hline 21 & Central Sulawesi & 45 & 5.0 \\
\hline 22 & Maluku & 15 & 1.7 \\
\hline 23 & North Maluku & 15 & 1.7 \\
\hline \multirow[t]{2}{*}{24} & North Sulawesi & 45 & 5.0 \\
\hline & Total & 900 & 100 \\
\hline
\end{tabular}

Table 2. Distribution of Compliance with SFZ, Number of Schools in Indonesia

\begin{tabular}{|c|c|c|c|}
\hline \multicolumn{2}{|c|}{ Value of compliance } & \multicolumn{2}{|c|}{ Number of schools $(n=900)$} \\
\hline Score & $\%$ & $\mathrm{f}$ & $\%$ cum \\
\hline 0 & 5,0 & 45 & 5,0 \\
\hline 1 & 3,0 & 27 & 8,0 \\
\hline 2 & 1,1 & 10 & 9,1 \\
\hline 3 & 2,6 & 23 & 11,7 \\
\hline 4 & 3,3 & 30 & 15,0 \\
\hline 5 & 6,9 & 62 & 21,9 \\
\hline 6 & 11,9 & 107 & 33,8 \\
\hline 7 & 20,3 & 183 & 54,1 \\
\hline 8 & 45,9 & 413 & 100,0 \\
\hline
\end{tabular}

in the school environment, had the largest proportion when a school did not apply SFZ. Cigarette butts were found in $261(29.0 \%)$ schools. Cigarette butts found in schools contributed 7.8 times to not applying SFZ compared to schools where no cigarette cutters were found (Table 3).

\section{Discussion}

The impact of policies on implementing a regulation is very influential (Sibarani, 2017). In educational facilities such as formal schools, policies related to tobacco control are very influential in suppressing the smoking behavior of students (Rachmat et al., 2013; Rochayati

Table 3. Inferential Analysis of the Most Influential Parameters in the Application of SFZ in Indonesia

\begin{tabular}{|c|c|c|c|c|c|c|c|c|c|}
\hline \multirow[t]{3}{*}{ No. } & \multirow[t]{3}{*}{ SFZ parameter } & \multicolumn{4}{|c|}{ SFZ compliance } & & & \multicolumn{2}{|c|}{ Chi-square } \\
\hline & & \multicolumn{2}{|c|}{ No } & \multicolumn{2}{|c|}{ Yes } & \multicolumn{2}{|c|}{ Total } & \multirow[b]{2}{*}{ Prevalence Ratio (PR) } & \multirow[b]{2}{*}{$95 \% \mathrm{CI}$} \\
\hline & & $\mathrm{f}$ & $\%$ & $\mathrm{f}$ & $\%$ & $\mathrm{f}$ & $\%$ & & \\
\hline \multirow[t]{3}{*}{1} & \multicolumn{7}{|c|}{ Found place/room/location for smoking } & 3.97 & 3. $471-4.541$ \\
\hline & Yes & 122 & 93.8 & 8 & 6.2 & 130 & 100 & & \\
\hline & No & 182 & 23.6 & 588 & 76.4 & 770 & 100 & & \\
\hline \multirow[t]{3}{*}{2} & \multicolumn{7}{|c|}{ Found no sign of smoking in the school environment } & 4.093 & $3.528-4.747$ \\
\hline & Yes & 145 & 16.1 & 19 & 2.1 & 164 & 100 & & \\
\hline & No & 159 & 21.6 & 577 & 64.1 & 736 & 100 & & \\
\hline \multirow[t]{3}{*}{3} & \multicolumn{7}{|c|}{ Could smell cigarette smoke in the school environment } & 4.793 & $4.133-5.559$ \\
\hline & Yes & 157 & 95.7 & 7 & 4.3 & 164 & 100 & & \\
\hline & No & 147 & 20 & 589 & 80 & 736 & 100 & & \\
\hline \multirow[t]{3}{*}{4} & \multicolumn{7}{|c|}{ Ashtrays and/matches were found in the school environment/surroundings } & 5.611 & $4.777-6.589$ \\
\hline & Yes & 179 & 97.8 & 4 & 2.2 & 183 & 100 & & \\
\hline & No & 125 & 17.4 & 592 & 82.6 & 717 & 100 & & \\
\hline \multirow[t]{3}{*}{5} & \multicolumn{7}{|c|}{ Cigarette butts were found in the school environment } & 7.83 & $5.833-10.512$ \\
\hline & Yes & 261 & 66.4 & 132 & 33.6 & 393 & 100 & & \\
\hline & No & 43 & 8.5 & 464 & 91.5 & 507 & 100 & & \\
\hline \multirow[t]{3}{*}{6} & \multicolumn{7}{|c|}{ Found people smoking in the school environment } & 4.75 & $4.090-5.516$ \\
\hline & Yes & 158 & 94.6 & 9 & 5.4 & 167 & 100 & & \\
\hline & No & 146 & 19.9 & 587 & 80.1 & 733 & 100 & & \\
\hline \multirow[t]{3}{*}{7} & \multicolumn{7}{|c|}{ Found tools/items that had logos related to cigarette advertisements, promotions, and sponsors } & 3.885 & $3.430-4.401$ \\
\hline & Yes & 106 & 97.2 & 3 & 2.8 & 109 & 100 & & \\
\hline & No & 198 & 25 & 593 & 75 & 791 & 100 & & \\
\hline \multirow[t]{3}{*}{8} & \multicolumn{7}{|c|}{ Found a person or place that sold cigarettes in the school environment } & 4.129 & $3.641-4.683$ \\
\hline & Yes & 116 & 99.1 & 1 & 0.9 & 117 & 100 & & \\
\hline & No & 188 & 24 & 595 & 76 & 783 & 100 & & \\
\hline
\end{tabular}


and Hidayat, 2015). This study suggests one effective strategy for controlling tobacco through the presence of letters of decree/instructions/special regulations that can have an impact on the application of SFZ in schools. The application of SFZ in a school is followed by the existence of a letter of decree/instructions/special regulations regarding smoking behavior in schools (Renaldi, 2014). This study implies that schools that implement SFZ should issue special instructions with either a decree issued by the school or special attention for students, teachers, and school residents regarding SFZ in the school.

In addition, schools that apply SFZ also give significantly more attention through special assignments to officers who have the main tasks and functions in monitoring SFZ violations. Although not specifically, these officers have the responsibility to oversee the application of SFZ in schools (Renaldi, 2014; Vermeir et al., 2015). This task can be managed by teachers, security officers, and even students, who can report if violations of school rules are discovered.

No doubt, the cigarette industry is always thinking about and finding effective ways to promote cigarettes, including to teenage students (Krueger, 2019; Robertson et al., 2016). The youth market is the main target for the cigarette industry among all age groups because of its potential to bind adolescents to smoking for life with the narcotic effects provided by the nicotine substances contained in each cigarette (point-of-sale-POS - for captive market) (Douglas et al., 2016; Shang et al., 2016). One of the effective ways the cigarette industry targets teens is by sponsoring education as one of the basic needs of adolescents besides sports (Perbawa et al., 2019). Providing assistance in the form of scholarships to sponsor an activity or school, even by building a school or a foundation, is an effective strategy in guaranteeing this POS for teenagers, including school students (Krueger, 2019; Putranto, 2019).

Why there is no FCTC mention in this paper?

Nowadays, Indonesia should be the biggest one within nine countries in the world who had not yet ratified the international convention of tobacco control, namely Framework Convention on Tobacco Control (FCTC). Instead, Indonesia records more than sixty million active smokers and lost productivity costs due to cancers related to secondhand smoking which is significant source of high economic burden in Indonesia (Kristina et al., 2019). Although Indonesia has issued several national regulations on tobacco control, it assumes that the existing policies fall short when compared to the others countries who has been implement FCTC (Ahsan et al., 2020). One of the its terms is the fresh air regulation in order to environmental tobacco smoke protection.

Actually, Indonesia has released the Government Act No. 36 of 2009 about health in article 115 (Republic of Indonesia Government, 2009). In this national regulation, smoking behavior restriction should be done in public places particularly when young people and children are existed, including in education facilities. However, this government act can only be applying when local government's regulation (Perda/Perwali/Perbup/Pergub) has been set by each regency (districts/cities) (Achadi, 2008; Sulistiadi et al., 2020; Veruswati et al., 2018). It means that the tobacco control policy in a school within a regency is highly depend on each local government whether they are already set this regulation or not. Thus, established evidences suggested that the SFZ campaign and strategies are necessary to all parties not only to the local government, but also to mass community (Veruswati et al., 2020) including students (Hettiarachchi et al., 2020) should be taken into account in reducing the youth smokers as the designated mission of all countries with high burden of tobacco consumption.

In conclusion, although the SFZ compliance rate in Indonesian schools is $66.2 \%$ at least on 7 of 8 existed parameters, this means that most of schools still do not fully comply with the SFZ regulations. This evaluation of the implementation of SFZ was an effort to monitor and evaluate the agenda of the government programs or activities in the health sector to achieve the objectives of both Renstra and RPJMN indicators. Therefore, implementation will be effective if there is joint responsibility, cooperation, and commitment across programs and across sectors.

\section{Acknowledgements}

This study was supported by the Internationallyindexed Publication (PUTI) of Directorate for Research and Development - Universitas Indonesia (Risbang-UI) Grant Award. Its content is solely the responsibility of the authors and does not necessarily represent the official views of the authors' affiliations.

\section{Conflict of interests}

CPA, TSDR, and AH are board member at Directorate of Non-Communicable Disease Control and Prevention (P2PTM), Indonesian Ministry of Health, one of the government organizations advocating for higher smoke-free compliances in Indonesian schools.

\section{Author contributions}

AA was involved in the conception and design of the study, data analyses, interpretation of results and wrote the first draft of the manuscript. MV was involved in the conception and design of the study, carried out the data analyses, interpretation of results and drafting the manuscript. CPA, TSDR, and AH were involved in the conception and design of the study, data collection and interpretation of results. All authors read and approved the final manuscript.

\section{References}

Achadi, A (2008). Regulasi pengendalian masalah rokok di Indonesia. Kesmas: Jurnal Kesehatan Masyarakat Nasional (National Public Health Journal), 2, 161-5.

Ahsan A, Wiyono NH, Veruswati M, et al (2020). Comparison of tobacco import and tobacco control in five countries: lessons learned for Indonesia. Globalization Health, 16, 1-8.

Balitbangkes (2013). Laporan Hasil Riset Kesehatan Dasar (Riskesdas) Tahun 2013. Badan Penelitian dan 
Pengembangan Kementerian Kesehatan Republik Indonesia.

Douglas M, Chan A, Sampilo M (2016). Youth advocates' perceptions of tobacco industry marketing influences on adolescent smoking: Can They See the Signs?. AIMS Public Health, 3, 83.

Hettiarachchi P, Jayasooriya P, Amarasinghe H, et al (2020). Knowledge and attitudes of nursing students towards smokeless tobacco and Areca Nut control in central Province of Sri Lanka. Asian Pac J Cancer Care, 5, 133-8.

Kristina SA, Permitasari NPAL, Ahsan A (2019). The premature mortality cost of cancers attributable to secondhand smoking in Indonesia. Asian Pac J Cancer Care, 4, 107-12.

Krueger JP (2019). Industry response to this finding.

Ministry of Health - Republic of Indonesia (2011). Pedoman Pengembangan Kawasan Tanpa Rokok (Guideline for Development of Smoke-Free Zone). In Pusat Promosi Kesehatan, Jakarta (pp. 9-13). Ministry of Health - Republic of Indonesia.

Ministry of Health - Republic of Indonesia and Ministry of Home Affairs - Republic of Indonesia. (2011). A Joint Regulation between Ministry of Health and Ministry of Home Affairs, Republic of Indonesia, No: 188/MENKES/PB/I/2011; No: 7/2011 about Smoke-Free Zones. Kementerian Kesehatan bersama Kementerian Dalam Negeri Republik Indonesia.

Perbawa IR, Handayani KN, Suparno S (2019). PENERAPAN KONSEP SEMANTIK PADA WADAH EDUKASI NONFORMAL INDUSTRI PUSAKA KRETEK. Senthong, 2.

Prasad V, Sy JM (2020). Building momentum for tobacco control in the Western Pacific Region. Asian Pac J Cancer Prev, 21, 1.

Putranto TD (2019). Wacana Berita PT. Djarum dan Bulu Tangkis Indonesia. Jurnal Studi Komunikasi, 3, 27-40.

Rachmat M, Thaha RM, Syafar M (2013). Perilaku merokok remaja sekolah menengah pertama. Kesmas: National Public Health Journal, 7, 502-8.

Renaldi R (2014). Implementasi Kebijakan Kawasan Tanpa Rokok (KTR) pada Mahasiswa di Lingkungan Sekolah Tinggi Ilmu Kesehatan Hang Tuah Pekanbaru. Jurnal Kesehatan Komunitas, 2, 233-8.

Republic of Indonesia Government (2009). Government Act No. 36 about Health (Undang-Undang Republik Indonesia No. 36 Tentang Kesehatan). Republic of Indonesia Government.

Robertson L, Cameron C, McGee R, et al (2016). Point-of-sale tobacco promotion and youth smoking: a meta-analysis. Tobacco Control, tobaccocontrol-2015.

Rochayati AS, Hidayat E (2015). Faktor-Faktor Yang Mempengaruhi Perilaku Merokok Remaja di Sekolah Menengah Kejuruan Kabupaten Kuningan. Jurnal Keperawatan Soedirman, 10, 1-11.

Shang C, Huang J, Cheng K-W, et al (2016). Global evidence on the association between POS advertising bans and youth smoking participation. Int J Environ Res Public Health, 13, 306.

Sibarani R (2017). Tantangan Tata Kelola Kebijakan Perubahan Iklim di Indonesia (Studi Kasus: Komparasi Antara Penerapan Desentralisasi dan Multi-Level Governance). Jurnal Hukum Lingkungan Indonesia, 4, 61-86.

Sulistiadi W, Veruswati M, Asyary A, et al (2020). Smoke-free Zone in Indonesia: Who is Doing What Now. Open Access Macedonian J Med Sci, 8, 322-4.

Vermeir P, Vandijck D, Degroote S, et al (2015). Communication in healthcare: a narrative review of the literature and practical recommendations. Int J Clin Pract, 69, 1257-67.

Veruswati M, Asyary A, Nadjib M, et al (2018). Current activities in smokes-free zone policy: a tobacco control care reviews in Indonesia. Fam Med Prim Care Rev, 20, 10-3.

Veruswati M, Asyary A, Sucipto E, et al (2020). Perceived community support about the implementation of a smoke-free environment regional regulations in the Tegal municipality. Fam Med Prim Care Rev, 22, 222-7.

Widodo J (2014). President of Republic Indonesia's Speech: Badan Perencana Pembangunan Nasional/Kementerian Perencanaan Pembangunan Nasional. Bappennas/ KemenPPN RI.

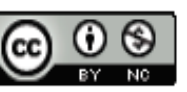

This work is licensed under a Creative Commons AttributionNon Commercial 4.0 International License. 